\title{
Science, technique, technology: passages between matter and knowledge in imperial Chinese agriculture
}

\author{
FRANCESCA BRAY*
}

\begin{abstract}
Many historians today prefer to speak of knowledge and practice rather than science and technology. Here I argue for the value of reinstating the terms science, techniques and technology as tools for a more precise analysis of governmentality and the workings of power. My tactic is to use these three categories and their articulations to highlight flows between matter and ideas in the production and reproduction of knowledge. In any society, agriculture offers a wonderfully rich case of how ideas, material goods and social relations interweave. In China agronomy was a science of state, the basis of legitimate rule. I compare different genres of agronomic treatise to highlight what officials, landowners and peasants respectively contributed to, and expected from, this charged natural knowledge. I ask how new forms of textual and graphic inscription for encoding agronomic knowledge facilitated its dissemination and ask how successful this knowledge proved when rematerialized and tested as concrete artefacts or techniques. I highlight forms of innovation in response to crisis, and outline the overlapping interpretative frameworks within which the material applications of Chinese agricultural science confirmed and extended its truth across space and time.
\end{abstract}

When Joseph Needham began publishing Science and Civilisation in China just over fifty years ago, a routine criticism was that he implied misleading connections between science and technology. Needham divided the work into volumes corresponding to the major modern 'pure' sciences (mathematics, physics, chemistry, biology), each followed by corresponding applied sciences or technological fields. Magnetism and building, for instance, fell respectively under the categories of applied physics and physical technologies. This strategy for connecting ideas and matter expressed Needham's belief in the reciprocal impact of science and technology, scholarly and artisanal knowledge, in the production of science. ${ }^{1}$ At another level of communication, it also reflected the everyday connections people draw between 'pure' and 'applied' scientific knowledge. This was certainly an important factor in the immense public success of Needham's project. Within the discipline of history of science, however,

* Social Anthropology, School of Social and Political Studies, Adam Ferguson Building, George Square, Edinburgh EH8 9LL, UK. Email: Francesca.bray@ed.ac.uk.

I should like to thank Ramon Guardans, Sandy Robertson, Simon Schaffer, Yung Sik Kim and the anonymous reviewers of BJHS for their most helpful criticism and suggestions, and my warmest thanks to Marjorie Senechal and Charlotte Furth for encouraging me to persevere.

1 Here Needham acknowledged Edgar Zilsel as an important influence: J. Needham, 'Preface', in The Social Origins of Modern Science, E. Zilsel (ed. Diederick Raven, W. Krohn and R. S. Cohen), Dordrecht and Boston, 2000, pp. xi-xiv. 
critics like Lynn White raised strenuous objections, arguing that by adopting a framework that designated technological activities as applied forms of science, Needham used premodern China's undoubted technical brilliance to imply an exaggerated level of scientific achievement. ${ }^{2}$

Meanwhile, in his influential collection of essays entitled Clerks and Craftsmen in China and the West, ${ }^{3}$ after arguing for the fertile contributions of interactions between officials and craftsmen in the early phases of Chinese history, Needham suggested that in the long run Confucianism and the bureaucratic concerns of the late imperial state were inimical to the pursuit of science and technology, not least because the neoConfucians who came to dominate the late imperial governing elite held artisans and their working knowledge in low esteem. In other words, Needham was inclined to argue for a chasm between the academic knowledge valued by the late imperial state, and the craft skills that built the material world it governed.

This position has since been amply refuted by an impressive body of research charting the relations between rule, knowledge and material action in late imperial China. What constituted significant or crucial domains of natural knowledge in China did not always conform to Western patterns. Nevertheless, as recent scholarship has amply demonstrated, the late imperial Chinese state and its officers played key roles in producing and disseminating new forms of scientific knowledge, and in mobilizing technical instruments or practices to generate such knowledge, particularly in domains of such obvious statecraft relevance as astronomy or hydraulics. ${ }^{4}$ Following the strictures of the new critical history of Western science, however, and still recoiling from Needham's supposedly imprudent and profligate use of these terms, except when referring to imports from the West, historians of China often prefer to speak of knowledge and practice rather than science and technology.

In this paper I want to argue for the value of reinstating the terms science, techniques and technology as tools for a more precise analysis of governmentality and the workings of power in the late imperial Chinese state. My tactic is to use these three categories explicitly, in order to highlight flows between matter and ideas in the production and reproduction of knowledge. To this end I propose the following definitions. ' 5 cience' I define as knowledge about natural, material processes expressed in declarative, transmissible form; its representations generally aspire to be authoritative beyond the time and place of their production. 'Techniques' I define as the skilled practices that go into the material production of knowledge as well as the production of artefacts. 'Technology' denotes social-material networks or systems, including sets of techniques and equipment, but also trained personnel, raw materials, ideas and institutions.

2 L. White Jr. 'Symposium on Joseph Needham's Science and Civilisation in China', Isis (1984), 75, $715-25$.

$3 \mathrm{~J}$. Needham, Clerks and Craftsmen in China and the West: Lectures and Addresses on the History of Science and Technology, Cambridge, 1967.

4 For a recent overview of much of this work see B. A. Elman, On Their Own Terms: Science in China, 1550-1900, Cambridge, MA, 2005.

5 Like Malinowski's reformulation of the distinctions between magic, religion and science, I would argue that, thus defined, science, techniques and technology constitute three interlocking categories which can be found in any human society. B. Malinowski, Magic, Science and Religion and Other Essays, London, 1925. 
Technology in this sense of networks or systems is here of twofold interest, first as generating material goods and social relationships, and second as contributing to the production or reproduction of the kind of knowledge I have termed 'science'. Thus defined, science, techniques and technology are not separate kinds of activity but rather overlapping phases of an organic process of knowledge production.

The case I will discuss is agriculture. Farming is a material activity that spans the gap between premodern societies and our contemporary world. It is very obviously a materially rooted domain of knowledge, embedded in social networks. It is furthermore a domain of technical knowledge and practice in which the Chinese state has actively intervened since its inception, recording and transmitting technical information, investing in infrastructure and improvements, and directing local practices.

Modern agriculture is generally thought of not as a science in itself, but rather as a science-based productive activity, in today's popular terms a technology, that applies knowledge from several scientific fields. Following this convention, agriculture, nong, was classified in Science and Civilisation as a 'biological technology'. ${ }^{6}$ But if, as historians, we take a science as a domain of natural knowledge considered primary in its own time, then in imperial China agriculture was a science in its own right. Throughout its duration imperial China was an agrarian empire in which the state levied taxes and landlords demanded rent from the peasantry. The land was the source of sustenance and of wealth, of production and extraction. Agriculture was not only the material but also the social and ethical basis of the polity, or, as Chinese political philosophers put it, the 'root' or 'foundation', ben. In consequence it was the object of systematic enquiry and intervention by the governing class.

What kinds of knowledge and whose knowledge were inscribed in the Chinese agricultural texts which have come down to us in such abundance, and in the farming landscapes whose distinctive features we can track over two millennia? Agriculture is a domain of knowledge where it is impossible to separate ideas about matter from the struggles with matter that generate them. Nor are the knowledge and techniques politically neutral. The norms of good farming are a very powerful instrument for ordering society. Agriculture, then, constitutes a wonderfully rich case of the intertwining of knowledge, practice and power; of the production of ideas, material goods and social relations. How is this reflected in the agricultural texts that circulated among the ruling Chinese elite and filtered down to peasant farmers through magistrates and landlords? I address the formation and the power of agricultural knowledge in imperial Chinese society explicitly in terms of the relations between science, techniques and technology. I offer selected examples of the material access to knowledge characteristic of the different groups of actors, and the various processes of their translation or encoding into textual or graphic inscriptions, including, for instance, how the threedimensional farm implements of peasants and their uses were translated into twodimensional printable form. I also address the question of how 'mobile' and how 'hard' the facts of Chinese agronomic science proved, given a written tradition that

6 See the title page of F. Bray, Science and Civilisation in China, Volume VI: Agriculture, Cambridge, 1984, p. v. 
developed over more than two thousand years, and dealt with (among other variables) a huge territory including deserts and tropical forests, dry plains and irrigated rice-lands.

Before plunging into the Chinese materials, I begin with a general discussion of the relations between ideas and matter, knowledge and power, in terms suggested by recent science and technology studies. Here I take modern agriculture as the illustration because it is helpful to argue through familiar facts the case for the rather special definitions of science, technology and technique just proposed. In this section I focus on how knowledge flows between science, technology and technique, its passages from matter to idea and back. I discuss processes of inscription and what Feenberg calls the 'codes' embodied in such inscriptions, and draw on Latour's concepts of 'immutable mobiles' and 'hardening the facts' to address connections between technology and empire. $^{7}$

\section{Science, technique and technology}

In the framework of Science and Civilisation, Needham divided domains of natural knowledge into the knowledge, or science, itself and its applied form, the associated technologies. This approach reflects what Pfaffenberger calls the 'standard view' of science and technology, ${ }^{8}$ a model of the relations between ideas and matter that became conventional with the parallel rise of academic scientific disciplines and of engineering and industry in the nineteenth century. Although dismissed by today's historians of science as a discredited caricature, versions of the 'standard view' still regularly surface among scientists, educators and the general public, and despite its problems this model of knowledge flow offers some illuminating insights into the material production of formalized human knowledge.

The 'standard view' makes a categoric distinction between science and technology. Science offers new understanding about the nature of matter. It quarries the messy material stuff that surrounds us; it isolates, identifies, purifies and studies nuggets of it, then dematerializes the natural stuff into elegant ideas of universal validity expressed in verbal or numerical form. Technology takes the universal knowledge generated by science and applies it systematically to specific transformations of matter, thus rendering the world in which we live more orderly, productive and convenient. Knowledge is produced by scientists and flows in one direction: from science to technology, from the laboratory to the factory.

This model of the production and application of ideas about matter left little or no place for the kind of embodied knowledge characteristic of preindustrial production, what we might refer to as 'craft' or 'skill', knowledge embodied in techniques. Techniques are customary procedures for the transformation of matter that are routinized yet flexible, for they have to cope with the variations typical of natural

7 A. Feenberg, Questioning Technology, London, 1999; B. Latour, Science in Action, Cambridge, MA 1987.

8 B. Pfaffenberger, 'Social anthropology of technology', Annual Review of Anthropology (1992), 21, $491-516 ; 493-5$. 
materials. ${ }^{9}$ Furthermore, techniques are notoriously resistant to translation into either words or numbers. The technology of industrial production was understood as epistemologically distinct from artisanal techniques, in two senses. First, it involved the conscious application of previously formalized scientific knowledge to material processes. Second, the logic of industrial design was to eliminate the material irregularities that were the true test of a craft-worker's skills, while building as much as possible of the regularized processual core of a productive process into the machinery itself. The production of scientific knowledge, meanwhile, was understood as essentially a disembodied process: the mind was crucial, the hand only incidental - even the hand of the scientist conducting the experiment.

Recent scholarship has brought techniques back into both science and technology, looking from a variety of perspectives at how ideas and matter connect through concrete practices. Historians, anthropologists and sociologists of science now routinely treat sciences (at least sciences as they have emerged in the post-Renaissance West) as materially rooted practices in which the materiality both of the object of study and of its observation is intrinsic to the generation of knowledge. Techniques and skills are reestablished as an essential element in the generation of scientific ideas, a key dimension of experiencing, perceiving and knowing matter. Parallel arguments are made for technology. Standardized procedures have to be adjusted through skill and technique to adapt to the roughness and intransigence of real matter in its local context. The questions thus raised may generate new scientific research programmes. ${ }^{10}$ In other words, science is not just knowledge about matter; it is also knowledge that comes through matter. Techniques mediate dialectically between knowledge and matter. As such they are essential both to scientific investigation and to technological practice, underlining the epistemological continuities between the two domains.

Another point that recent history and sociology of science have effectively hammered home is that science is not the private activity of lone geniuses but a communicative activity. Sociologists of technology distinguish between invention and innovation. Devising a new solution to a material problem in your garden shed is very gratifying, but only if the solution is taken up by society at large will your thrilling new device step into history. Similarly, the impact of a new fact or theory in science depends not simply on its accuracy but on how effective it is first in persuading fellow scientists, and then in translating into ideas or institutions that affect society at large. Hence the recent emphasis on inscription, on social networks, and on the translation of science into what Foucault has referred to as governmentality and technologies of power.

To be validated, science has to persuade people. To function as science - that is, as knowledge legitimated within a scientific community - knowledge must be expressed in declarative form. It is at that level that it is tested, contested, validated, and fitted into a system and so acquires power as an authoritative affirmation about the natural world.

9 See, for example, P. Lemonnier (ed.), Technological Choices: Transformation in Material Cultures since the Neolithic, London, 1993.

10 For instance J.S. Staudenmaier, SJ, Technology's Storytellers: Reweaving the Human Fabric, Cambridge, MA, 1985, 103 ff; M. Akrich, 'A gazogene in Costa Rica: an experiment in techo-sociology', in Lemonnier, op. cit. (9), 289-337. 
This applies equally to science now and in premodern societies, and it is the reason why I have chosen in this paper to define science as textually or graphically inscribed knowledge. In the process of inscription the knowledge is often further encoded by translating it into a specialist technical vocabulary, verbal or visual. The persuasive power of a scientific fact or theory is closely related to its ability to travel through time and space, and to subsume heterogeneity. Hence the drive in inscription to simplify, to homogenize, to produce representations of the nature of material processes that are accepted as generally valid beyond the time and place of their production. Latour calls such representations 'immutable mobiles', explanations or artefacts that can be transferred through space or time without requiring modification; as facts are 'hardened' into simpler and more mobile forms, more and more of the uneven contours of raw matter in its native environment are flattened out into manageable, regular elements. ${ }^{11}$

Part of the power of a scientific idea lies in its mobility and in the simplifications it is able to effect in its inscriptions. Part lies in its capacity to produce thick, dense, deeprooted networks that ensure its stability. Scientists persuade each other, and eventually the broader society within which they operate, not only by mustering plausible arguments but also by enrolling dense and durable networks of human, institutional and material supporters. The 'standard view' tells us that technology 'applies' scientific knowledge. But we can take this further, to urge that industrial and other technologies reshape the material world in ways that confirm the truth of the corresponding science. Technology rematerializes the abstract universals of science, reshaping our surroundings into new configurations almost as elegant in their simplicity as the equations that they embody. Messy natural stuff is processed into homogeneous materials: pure chemical compounds, precise alloys, wire of exact gauge, in other words the neat pieces that allow processes of mass production to function identically anywhere in the world, generating components or commodities of regular, geometrical shape and standardized size. Furthermore, while the 'standard view' represents knowledge as flowing out from science and into technology, recent studies have underlined how the constellation of social institutions, material artefacts and technical skills and practices (representing often huge financial, educational and political investments) which validates a set of scientific ideas often in fact directs the further development of that knowledge. ${ }^{12}$

Here I come to what Feenberg calls a 'technological code'. A technology is a material system in which tacit understanding and explicit science both play a role in naturalizing social hierarchies and encoding cultural values. Feenberg gives the example of factory machinery in early nineteenth-century Britain built to a scale suitable for child operators, thus encoding the social and legal endorsement of child labour. ${ }^{13}$ Another good example is the calculation of farming efficiency. Everyone knows that agriculture produces corn, and one easy way to measure the efficiency of a particular agricultural

11 B. Latour, 'Visualization and cognition: thinking with eyes and hands', Knowledge and Society: Studies in the Sociology of Culture Past and Present (1986), 6, 1-40, 17.

12 A good example is S. Traweek, 'Kokusai, gaiatsu and bachigai: Japanese physicists' strategies for moving into the international political economy of science', in Naked Science: Anthropological Inquiry into Boundaries, Power and Knowledge (ed. L. Nader), London, 1996, 174-97.

13 Feenberg, op. cit. (7), 85. 
technology is to measure how much corn per acre is produced. As a simple ratio, 'efficiency' thus calculated appears to be a natural, neutral way of evaluating one system in comparison to another: Iowa farmers are more efficient corn-growers than Mexican peasants. Yet once other factors are admitted into the analysis (levels of pollution or of consumption of fossil fuel, biodiversity, optimal farm size, numbers of people employed or gaining a livelihood, subsidies, national export policies, impact on farmers in developing economies), the political dimensions of the technology, and of the measures chosen to evaluate its performance, become plain.

Agriculture is a technology where it is usually rather easy to identify the social or political interests that lie behind what is defined as 'good practice' or 'good science'. 'Scientific' farming first emerged in Britain in the late eighteenth century as an activity for gentlemen landowners, their factors, and their educated and relatively prosperous tenants. The new methods of draining and consolidating fields, rotating crops and carefully controlling the breeding of livestock required large holdings and access to capital. This was a system of knowledge and practice that smallholders could not afford to adopt, nor could they effectively compete against it. The new science of farming embodied a capitalist logic of economies of scale in the pursuit of greater output and profits. By the mid-nineteenth century a range of industrially produced farm machines had been designed to substitute for human labour, allowing the smooth translation of the model to the vast, sparsely populated plains of the New World where grain was produced for world markets. By the end of the nineteenth century, industrial agriculture had established itself as the unchallenged model of best farming practice, supported by a worldwide network of railways and steamships, telegraph cables, factories producing farm machinery and fertilizers, commercial seed companies, land-grant and agricultural colleges, experimental stations and scientific societies. While the early forms of British scientific farming had encoded gentry farmers as their primary beneficiaries, since the mid-nineteenth century cutting-edge agricultural science, even in state institutions, has usually encoded the right of industry and commerce to extract profits from the farming sector. ${ }^{14}$

Just how far across time and space can 'good science' and 'efficient technology' spread their claims? Latour's concept of 'immutable mobiles' offers a useful way to think about how science and technology can exercise power over people, and about the challenges or obstacles that knowledge which claims general applicability may face when it attempts to conquer new territory. Modern agronomy produces inscriptions (both textual and material) that are widely believed to be universally valid. Modern farming practices draw upon a network of sciences, among them organic chemistry, genetics, soil science, and - increasingly - molecular biology. Scientific knowledge is produced in laboratories and experimental plots and then translated into technical artefacts (hybrid seeds, reaper-binders, chemical fertilizers, irrigation systems, crop rotations) which farmers around the world are taught to use. The institutions which

14 J. R. Kloppenberg, First the Seed: The Political Economy of Plant Biotechnology, 1492-2000, Cambridge, 1988; F. Bray, 'Genetically modified foods: shared risk and global action', in Revising Risk: Health Inequality and Shifting Perceptions of Danger and Blame (ed. B. H. Harthorn and L. Oaks), Boulder, CO, 2003, 185-207; J. Harwood, Technology's Dilemma, London, 2005. 
today support the intensification and further penetration of this normal science of farming include agricultural colleges, global trading networks, international funding agencies, national governments pursuing development, and the research of scientists employed either by public institutions or - increasingly - by agribusiness corporations.

The science and technologies of modern agronomy claim general validity. Yet the mobility of normal agricultural science's inscriptions, textual and material, is still impressive when we consider how vulnerable farming procedures are to local variations in soil or weather, to cite just two significant variables. In any application outside the lab the general principles of agricultural science have to be accompanied by instructions on how to adjust them to variations in local context; the inscriptions must be to some extent flexible. But at the same time, the farming methods generated by the inscriptions alter the environment in such a way as to reduce the need for their own modification. Modern agriculture offers a particularly dramatic but by no means unique example of how a technology (here in the sense of a set of material practices) works to create the conditions in which its science will be valid, and its techniques will work.

One common characteristic of technical artefacts is that they extend or multiply human capabilities: a plough as an extension of the human arm, a calculator as one of the brain. Another, less often remarked upon but equally significant, is to flatten out the irregularities of the world around us: buildings are warmer in winter and cooler in summer than the open air; agriculture (together with food storage and processing techniques) smoothes out seasonal fluctuations of supply or the impact of disasters. In the industrial era technology (in the sense both of a set of technical procedures and of a code or ideology) has notoriously been a flattener, homogenizing materials, processes and products around the world. Normal agriculture has moved steadily forward to greater scale and greater flattening power - quite literally, where bulldozers and lasers level ever-larger fields for the convenience of irrigation equipment and large-scale machinery; more metaphorically, where huge areas are devoted to a single crop (monoculture), and often to a single scientifically bred variety of a single crop. Irregularities of time are minimized. Every cornfield is sown with the same seed, and needs spraying or watering or harvesting exactly so many days after sowing; genetic modification now permits year-round cultivation and harvesting of strawberries. Space, too, is homogenized. Mountainsides are levelled, swamps drained and deserts irrigated till they bloom. This material technology is not unlimited in its powers to standardize local landscapes and climate. It is still more efficient, in financial and energetic terms, to grow corn in Iowa than in Alaska, but it would not be technically impossible to turn Alaska into corn farms, at least in the short term. The material technologies of industrial farming do more than simply apply the facts of normal agricultural science, they help turn them into harder facts by testing them against initially adverse conditions. And they give enormous mobility to their immutables (general principles of tillage, hybrid seeds) by transforming unfavourable local conditions into replicas, often on a giant scale, of the experimental station.

But if we look at normal scientific agriculture as a sociotechnical system, we see that its mobile immutables move more easily through some social networks than others. Like the scientific farming of the eighteenth century, the scientific facts and artefacts of 
the contemporary system encode productivist economies of scale and therefore work better for large-scale farmers with access to both land and capital; they have a tendency to eliminate smallholders. In nations like the United States, Canada or Britain, where normal agriculture took hold early, the weakness of smaller farms trying to operate within or as an alternative to this system is construed as inefficiency. In countries like India or France many small farmers soon learned to discern and challenge the code embodied in such apparently neutral artefacts as hybrid or genetically modified seed, and public support for small farmers claiming the political right to survive has obliged governments to moderate their initial enthusiasm for the new technologies. ${ }^{15}$

What is considered an efficient or a poor technique for sowing rice, a good or poor scientific rationale for the breeding of cattle, depends to a significant extent upon social and cultural context. Within a society that largely shares values and institutions across class and interest groups, the hardness of facts and the transportability of the immutables may be tested principally against local variations in natural conditions. But if the central state attempts to impose settled farming on swidden farmers, if landowners want to switch to sheep and throw out their tenants, or if tenant farmers adopt a new cropping system that undermines traditional rental arrangements, then these proposed transformations will meet fierce resistance. If the resistance is overcome and a new social contract is achieved, then agricultural science and technology will serve as powerful instruments for maintaining the new social order and for inculcating the subjectivities associated with that order. It can be argued that even in modern nations where it occupies only a small portion of the population and of national economic production, agriculture is still a fundamental instrument of governmentality and encoder of shared or contested social values. ${ }^{16}$ In an agrarian state like imperial China the symbolic and material importance of technical choices in agriculture was a constant preoccupation of the ruling elite.

\section{Agronomy as state science in late imperial China}

In the modern world it is taken for granted that governments play a key role in promoting agricultural science and progress, but this is a rather recent development. Although almost all states before the nineteenth century were built upon agrarian economies, few put the technical promotion of agriculture at the centre of their philosophy of rule. Most governments of Western states, for example, played little direct role in the production or dissemination of agricultural knowledge before the nineteenth century. ${ }^{17}$ Imperial China, however, was from its inception an agrarian state in the strong sense of the term. The production and circulation of agronomic knowledge by the state was a key technique of government.

15 Bray, op. cit. (14).

16 For the contemporary USA see, for example, E. Schlosser, Fast Food Nation, New York, 2001; and for the contrast with France see Bray, op. cit. (14).

17 The United States was a pioneer, setting up an embryonic Department of Agriculture in 1836 as a branch, significantly, of the Office of the Commissioner of Patents. 
What kind of 'agronomic science' did the imperial Chinese state produce? A great deal of the technical knowledge which the state produced and circulated under the heading of nong, agriculture, consisted of encodings of the material knowledge and skills of practising farmers in a precise specialist language developed over centuries. ${ }^{18}$ Certain types or forms, however, depended on the special resources available to officials, or reflected purely official concerns. Here I ask what official strategies for producing agronomic knowledge added to the technical knowledge of farmers. How did they select, encode and deploy knowledge, and for what ends, and how successfully could such encodings be decoded and rematerialized as techniques or artefacts? Were official inscriptions simply records of existing knowledge, or did official agronomists also create new forms of knowledge?

I will discuss these questions in relation to the evolution of agronomic knowledge during the late imperial period, focusing on three outstanding examples of agronomic treatises (nongshu) written by officials in the period between 1250 and 1650. To highlight their specific characteristics as state science, I compare their strategies for producing knowledge to those deployed in treatises written by private landowners during roughly the same period. The discussion starts with a brief sketch of the significance of agronomic knowledge in Chinese statecraft and some indications of how the relations between knowledge, material practices and matter were expressed and conceived.

At the core of the Chinese tradition of statecraft $\left(j i n g j i^{19}\right)$ was the recognition that nong (a term which simultaneously denoted farmers, farming practices, agricultural knowledge and the broad institutional category of agriculture) was the foundation (ben) of the human world, the fundamental occupation (benye) supporting the polity. An enduring agrarian ideal of the state represented the emperor and his officials as directly responsible for the well-being of a society formed essentially of smallholding peasant households, whose taxes (nominally a modest tenth of their production of cereals and cloth, except in times of extreme crisis) were the primary source of state revenues. ${ }^{20}$ Farming was the foundation not simply of the economy but of the social, moral and cosmic order of the imperial state. In late imperial China an iconic landscape of irrigated rice fields dotted with plantations of mulberry trees for feeding silkworms (Figure 1) represented not only a source of material abundance but also a setting in which humans acted out in microcosm the essential interflowing of yin (female) and yang (male) energies that sustained cosmic and political harmony. ${ }^{21}$

18 On the evolution of this technical language, its vocabulary and syntax, see F. Bray, 'Tecniche essenziale per il popolo', in La Scienza in Cina, in Enciclopedia internazionale della historia della scienza (ed. K. Chemla, F. Bray, Fu Daiwie, Huang Yilong and G. Métailié), Rome, 2001, 208-91.

19 From the classical expression jingshi jimin, 'to manage the realm and aid the people'.

20 See R. B. Wong, China Transformed: Historical Change and the Limits of European Experience, Ithaca, 1997, 90.

$21 \mathrm{~F}$. Bray, 'Instructive and nourishing landscapes: natural resources, people and the state in late imperial China', in A History of Natural Resources in Asia: The Wealth of Nations (ed. G. Bankoff and P. Boomgard), New York, 2007, 205-25. Before about 900 the dry northern plains had been the economic heartland of the Chinese state, but during the ninth century the balance began to shift towards the rice lands of Jiangnan (the lower Yangzi provinces) and other regions of the south. From Song times on, southern wet-rice farmers provided the bulk of the state's grain revenues and the empire's wealth. 


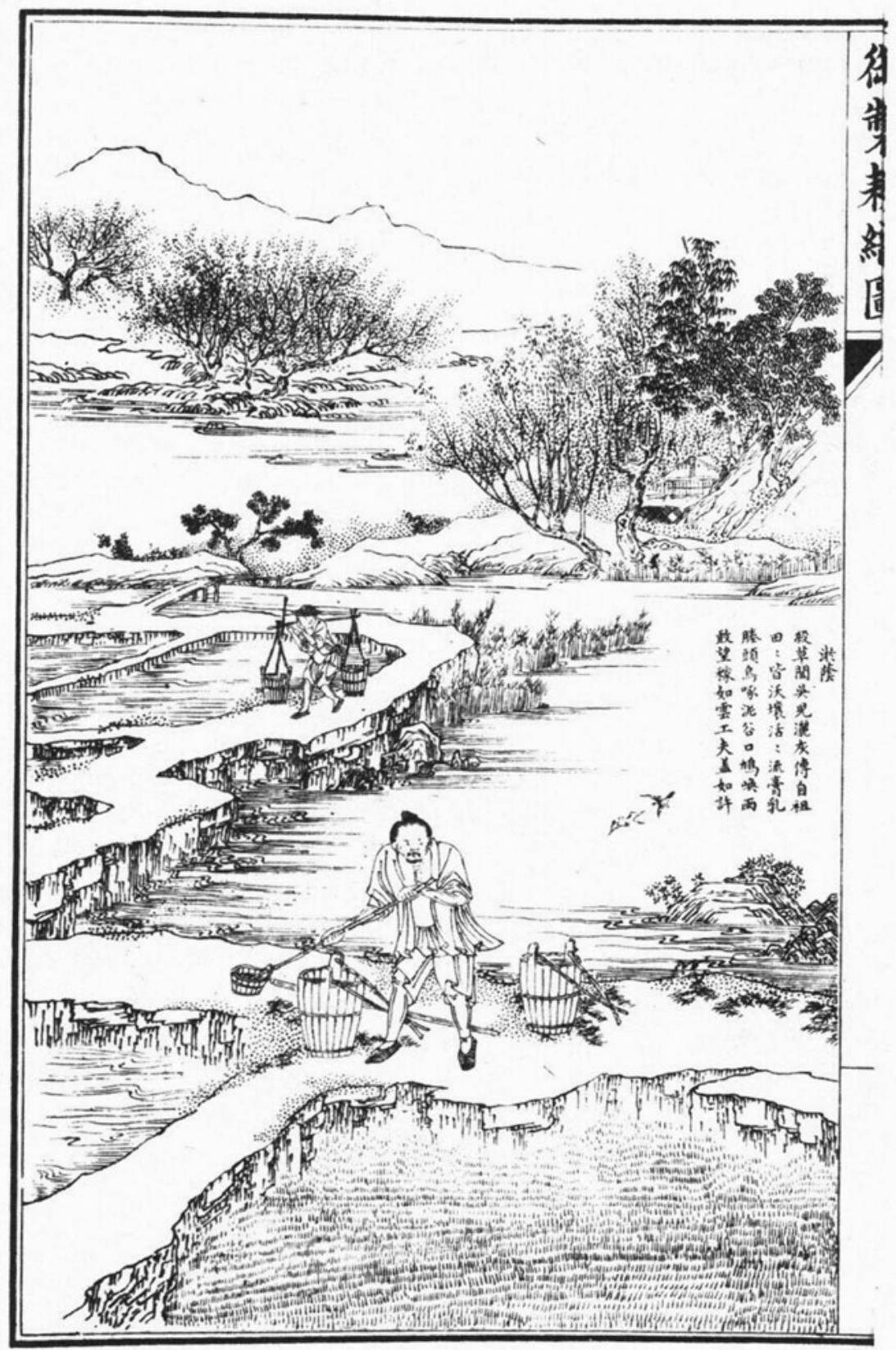

Figure 1. Fertilizing the rice fields - woodblock engraving from the series Gengzhi tu (Farming and Weaving Illustrated). The original set of paintings and poems, presented to the emperor in about 1145 by Lou Chou, magistrate of a district in Jiangnan, was copied and reworked many times. This version, commissioned by the Qianlong Emperor, dates from 1742. 
It was thus the duty of the emperor and his officials actively to promote agriculture (quannong) for reasons that were pragmatic (to increase state revenues and maintain social stability) but also cosmological and moral: to fulfil the Mandate of Heaven a virtuous ruler must devote himself to 'the welfare of the people' (limin), striving to improve their livelihood and to protect them from poverty and famine, from the risks of commerce and from exploitation by powerful landowners. ${ }^{22}$ Official instruction in effective farming methods helped peasant households to fulfil their part of the social contract, feeding and clothing both their families and the state. Proper farming practices also promoted and were in turn enhanced by the moral and social values of diligence, propriety and respect fitting to true subjects of the emperor. ${ }^{23}$

Quannong remained an active concern of statecraft throughout the two millennia of imperial rule, involving ritual as well as practical elements. ${ }^{24}$ According to the cosmological doctrine of the Three Powers (Sancai), humans (ren) occupy an intermediate position between Heaven (tian) and earth (di). Farming (nong) requires the application of human action (rengong) to draw benefits from the earth (dili), in coordination with the seasons of Heaven (tianshi). In a given environmental setting it was appropriate human action - high-level technical skills informed by good understanding of natural principles - that made the difference between good or poor harvests and between strong or weak states. Official policy, therefore, focused on developing rengong at the level of farmers' skills but also at that of local administration, provision of infrastructure, and national policy. ${ }^{25}$ The focus here is on the first level, of practical farming skills.

Chinese emperors, officials and state institutions all actively participated in the production, dissemination and application of agronomic knowledge on behalf of 'the people' (min) or 'farmers' (nongmin), a social category construed as peasants - simple, vulnerable and uneducated folk with few means and limited experience for whom it was the duty of officials to provide instruction and support. ${ }^{26}$ The ministry of agriculture

22 W. T. Rowe, Saving the World: Chen Hongmou and Elite Consciousness in Eighteenth-Century China, Stanford, CA, 2001.

23 See, for example, the section on 'Respecting rank and strengthening agriculture' (Xiaodi litian pian) in the introductory chapter to Wang Zhen's Nongshu (Agronomic Treatise) of 1313, in Wang Zhen Nongshu (critical ed. Wang Yuhu), Beijing, 1981 (hereafter WZNS), 17-19. Chinese rulers believed that teaching the barbarians who inhabited their borderlands to farm and weave the Chinese way would make good Chinese subjects of them: not only would they be able to pay their taxes, but they would learn to make the proper distinctions between male and female, right and wrong. S. Mann, 'Household handicrafts and state policy in Qing times', in To Achieve Security and Wealth: The Qing Imperial State and the Economy 1644-1911 (ed. J. K. Leonard and J. R. Watt), Ithaca, 1992, 75-95.

24 I discuss the intertwining of ritual or symbolic with materialist strategies in Bray, op. cit. (21).

25 See below on Xu Guangqi. On the concept of rengong see Li Bozhong, 'Changes in climate, land and human efforts: the production of wet-field rice in Jiangnan during the Ming and Qing dynasties', in Sediments of Time: Environment and Society in Chinese History (ed. M. Elvin and Tsui-jung Liu), Cambridge, 1998, 447-86, and in particular the passage he quotes from an essay by Lu Shiyi (1611-72) on intensive farming techniques (448). See also D. Schäfer, 'The congruence of knowledge and action: the Tiangong kaiwu and its author Song Yingxing', in Chinese Handicraft Regulations of the Qing Dynasty: Theory and Application (ed. H.-U. Vogel, C. Moll-Murata and Song Jianze), Munich, 2005, 35-60, for an extensive discussion of theories of the relations between cosmos and human action.

26 In fact the recipients of, or partners in, these outreach efforts also included landlords, much of whose land was worked by tenant farmers (see below). Shiba Yoshinobu, 'Environment versus water control: the 
promoted water control and land reclamation projects; collected and stored grain for famine relief or for price control; set up farming colonies for soldiers or refugees; offered tax relief, loans, seed and basic equipment to the poor; and circulated information about improved farming methods through the network of local magistrates. ${ }^{27}$ The official production of texts played a key role in circulating agronomic knowledge; these texts included technical pamphlets ${ }^{28}$ records kept at district, provincial or national level, imperial edicts and memorials to the throne; and agronomic treatises (nongshu - a genre also produced by landowners, as will be discussed below). It is on the treatises that I focus in the following discussion. With reference to media and techniques of inscription and transmission, woodblock printing was well established by the tenth century; both commercial and official printing and publishing houses played a prominent role in the production and circulation of agronomic knowledge. ${ }^{29}$

Agronomic treatises (nongshu) contain systematic observations and analyses of natural phenomena presented as authoritative knowledge (in the terms of the first part of this paper, 'science'). They tell the reader how to apply this knowledge by translating it into forms of material action ('techniques') that will draw benefits from the earth in the form of good harvests. As a medium of communication, nongshu encode scientific and technical information on paper, in technical verbal or graphic formulations that the reader is presumed able to decode, rematerialize and apply successfully. In all nongshu, whether composed by officials or landowners, techniques ( $f a n g$, technical knowledge; $\mathrm{fa}$, specialist methods; or shu, techniques or procedures) for cultivating and processing key crops are the centre of attention, along with farming tools or equipment (nongju or nongqi). However, the two genres of treatise, official and private, approach these techniques in different ways, and at the level of 'technology' (the techniques as part of a material-social system) and of 'science' (the ways in which natural knowledge is produced and the claims that are made for it) there are notable distinctions between them.

In order to highlight the governmental characteristics of official agronomy, its methods and goals, I begin with a brief account of nongshu written by landowners in late imperial times. ${ }^{30}$ These are usually short, just a few chapters. The author typically introduces the work as an addendum to earlier works, written to show how the general principles they contain should be modified to meet local conditions. Thus in 1647 the scholar-farmer Zhang Lüxiang (1611-74), who worked a smallholding in Tongxiang

case of the southern Hangzhou Bay area from the mid-Tang through the Qing', in Sediments of Time: Environment and Society in Chinese History (ed. M. Elvin and Tsui-jung Liu), Cambridge, 1998, 135-64, 159.

27 See e.g. M. Elvin, The Pattern of the Chinese Past, London, 1973; P. Golas, 'Rural China in the Song', Journal of Asian Studies (1980), 39, 2, 291-325; Bray, op. cit. (6); and idem, The Rice Economies: Technology and Development in Asian Societies, Oxford, 1986; P. Perdue, Exhausting the Earth: State and Peasant in Hunan, 1500-1850, New York, 1987; Li Bozhong, Agricultural Development in Jiangnan, 1620-1850, New York, 1998; W. T. Rowe, op. cit. (22).

28 A famous example is the instructions for growing quick-ripening Champa rice, introduced into the Yangzi delta on imperial order in 1012; see Bray, op. cit. (6), 492.

29 See, for example, L. Chia, Printing for Profit: The Commercial Publishers of Jianyang, Fujian (11th-17th Centuries), Cambridge, MA, 2002; Hu Daojing, Nongshu, nongshi lunji (Collected Essays on Agricultural Writing and Agricultural History), Beijing, 1985.

30 On earlier nongshu see, for example, Wang Yuhu, Zhongguo nongxue shulu (A Bibliography of Chinese Agronomy), 2nd edn, Beijing, 1979. 
district in the Yangzi delta, transcribed a manuscript on farming by a maternal relative called Shen. Shen had farmed in the district of Gui'an, which bordered Tongxiang, yet Zhang considered the technical differences sufficiently important to warrant writing a substantial supplement; for example, while farmers used ploughs in Gui'an, in Tongxiang the heavy damp soils were better tilled with hoes. As Zhang puts it in the preface to his supplement, completed in 1658, 'In farming there are the roots and the branches, the fundamentals and the secondary matters. Master Shen has perfectly covered all the fundamentals; what I say simply deals with some secondary matters. ${ }^{{ }^{31}}$

Not all landowner authors were as polite about their predecessors. In 1149 Chen Fu completed his Nongshu, a succinct but highly influential farming treatise which documented in precise detail the most sophisticated rice-farming and sericultural techniques current in the lower Yangzi region (Jiangnan). Chen states that he wrote it to refute the 'empty words', kong yan, of Jia Sixie concerning rice cultivation. ${ }^{32} \mathrm{Pu}$ Songling (1614-1715) was more typical in how he packaged his knowledge. A writer best known today for his gripping tales of the supernatural, ${ }^{33} \mathrm{Pu}$ also ran the family farm in Shandong. In 1705 he completed a farming handbook entitled Nongsang jing (Classics of Farming and Sericulture), which he presented as an adaptation of a magisterial earlier work to local conditions: $:^{34}$

Long ago Master Han wrote his 'Farming Instructions', a work so clearly expressed that even silken-breeched dandies and book-festooned scholars could understand the farming matters [it describes]. I read the work and thought it excellent. However some of what it says is incomplete, while other parts apply here but cannot be applied there; I have therefore made both cuts and additions... Although this work cannot transform the whole world, some people may hand it down to their sons and grandsons. ${ }^{35}$

The authors of landowner nongshu inscribed locally successful techniques. As far as cultivation methods are concerned, the best practices they recorded were typically not specific to the landowning class, for intensive wet-rice cultivation worked best at a small scale and success depended on fine-tuned skills rather than on access to capital or expensive equipment. ${ }^{36}$ Instead of concentrating their resources in large, centrally managed estates, working landowners gave most of their land out in small lots to tenant farmers, keeping only a small home farm for themselves. 'In my district', wrote Zhang

31 Bu nongshu (Supplemented Agricultural Treatise [by Master Shen]), hereafter BNS, in Bu nongshu jiaoshi (ed. Chen Huanli and Wang Dacan), Beijing, 1983, 9.

32 Nongshu (Agricultural Treatise), repr. Beijing, 1956, 1. Jia Sixie's Qimin yaoshu (Essential Techniques for the Common People), completed around the year 535, was printed and distributed by the Song government and in commercial editions. It offers an outstanding analytical conspectus of farming techniques suitable for dry-land northern farming (Bray, op. cit. (6), 55-9; and op. cit. (18)), but as a northerner Jia was clearly not an expert on irrigated rice.

$33 \mathrm{Pu}$ Songling, Strange Tales from a Chinese Studio (tr. John Minford), Penguin Classics, 2006.

34 Hanshi zhishuo (Master Han's Plain Words [on farming]), a work describing northern farming practices which probably dates back to the thirteenth century and has been preserved only in quotations. Wang Yuhu, op. cit. (30), 106-7.

35 Li Changnian (ed.), Nongsang jing jiaozhu (Annotated Critical Edition of the Nongsang jing), Beijing, 1982, 3, emphases added.

36 Bray, The Rice Economies, op. cit. (27), 113-16. 
Lüxiang, 'even a superior farmer can only manage $10 m u$ [0.6 hectare] of land, wet and dry [rice fields, and mulberry orchards for sericulture, respectively], so if a family has a surplus of land they will let a tenant farm it and take his rent'.${ }^{37}$ In the absence of economies of scale, best practice was equally accessible to landlords and tenants. As an example, by the end of the Ming it was common in Jiangnan for rice crops to be fertilized not only as seedlings but also just after the plants flowered, using powdered oil-cake. ${ }^{38}$ This practice was called 'carrying on the power' (jieli). Master Shen noted that the amounts and timing of these supplementary fertilizers depended on correctly assessing the weather and the state of the crops, and thus on skill and experience: extremely poor farmers who could not afford the supplements would suffer from meagre harvests, but, equally, wealthier farmers who used too much fertilizer indiscriminately would end up with lots of straw and empty husks. ${ }^{39}$ Many of the small innovations that cumulatively contributed to a steady increase in the productivity of Chinese agriculture through the late imperial period were due to peasant as much as landlord ingenuity. ${ }^{40}$ The fact that so many improvements described in agronomic texts were anonymous, tied to a district rather than a name, suggests humble origins.

What did landowners add to the technical knowledge of cultivation methods shared with peasant farmers? Their nongsh $u$ wove these materials into the broader technological context of running a working farm with more resources than most peasants would possess. Issues discussed include labour hire, how much land to keep as the home farm, how to select good tenants, and the relative profits $(l i)$ to be made from different crops or processing activities. Here is part of Master Shen's discussion of whether it is more profitable to hire male farmworkers or female silk-weavers:

Two women will weave 120 bolts of plain silk a year [each weighing 10 Chinese ounces or 1 Chinese pound]. Each ounce of plain silk is usually worth 1 string of cash [one-tenth of an ounce of silver], so for 120 bolts, after paying for 700 ounces of warp thread worth 50 ounces of silver and 500 of weft worth 27, plus the cost of reels and other equipment and wax for the yarn at 5 ounces, and 10 ounces for the women's food - altogether something over 90 ounces of silver - there remain 30 ounces' profit $[l i]^{41}$

Although the general principles of these managerial issues might travel through time and space, the specific details and calculations of profit did not. The information concerning cropping techniques was likewise expressly local, discussing only those crops and methods suitable for the region, and dwelling on the specifics of local methods and timing. For convenience of use, landowner nongshu were often organized in the form of a highly localized monthly calendar integrating the whole range of field, household and managerial tasks. Because the authors were instructing inhabitants of the same local landscape, their children and neighbours, or (indirectly) their tenants and farm

37 BNS, op. cit. (31), 148; see also Bray, op. cit. (6), 297.

38 The wheels of fibrous residue from pressing rape, sesame or hempseed oil were widely sold for fertilizer by the time of late Ming.

39 BNS, op. cit. (31), 35.

40 Li Bozhong, op. cit. (25).

41 BNS, op. cit. (31), 76-7. 
labourers, ${ }^{42}$ the process of decoding was relatively simple. These authors did not bother to describe basic tillage techniques or farm equipment, nor did they include illustrations. They saw the virtue of the agronomic science they offered as being its local specificity, a necessary correction to instructions that were too general, or designed for other localities. The authors, then, made deliberately modest claims for the mobility of their knowledge, and these nongsh $u$ typically circulated in manuscript rather than being printed. $^{43}$

The goal of official nongshu, in contrast, was to produce comprehensive, mobile knowledge that could successfully be transferred through the medium of print, across the vast spaces of the empire, and translated into local action. The knowledge they contained was directed at fellow officials whose duties included raising the standards of farming, and of the rural economy more generally, in the area for which they were responsible.

Unlike landowner nongshu, which presented the techniques of farming in the context of a technology of farm management, official nongshu embedded farming techniques in a matrix of government administration and statecraft concerns. They opened with sections on what we might call the ideology and cosmology of agrarian empire (discussed above). As well as sections on crops and cultivation techniques, they contained technical chapters on methods of land reclamation (kentian) and field systems (tianzhi - how to construct various types of irrigated field, polders, terraces and so on), on water control and hydraulic projects (shuili), on the construction and management of public granaries and on famine foods - all routine concerns for officials. The technical information on farming methods was not intended to teach magistrates how to build a harrow or pinch out cotton themselves, it was a resource for educating and training local farmers. The decoding, the translation of knowledge back into material artefacts and practices and their dissemination, often required the enrolment of such mediators as 'instructor farmers' or 'skilled carpenters' (see below). Although official agronomists recognized the pedagogical utility of farming calendars and struggled to devise universal calendars that could be adapted according to simple principles to work in any climatic zone ${ }^{44}$ the overall arrangement of the nongshu was not by month but by self-contained topic. A chapter on rice began with a discussion of varieties and their characteristics, then proceeded systematically through seed selection, sowing and transplanting through to harvesting and storage requirements; the sequence was universal, the reader decided on the local timing.

One strategy official nongsh $u$ adopted for producing knowledge that they hoped could be successfully transplanted in new ground was to identify and document

42 See Pu Songling above; Jia Sixie said he wrote his work 'for the youngsters in my family' (Bray, op. cit. (6), 56); Zhang Lüxiang said he composed his for the benefit of neighbouring farmers (BNS, op. cit. (31), 9).

43 See Wang Yuhu, op. cit. (30). Seven manuscript copies of the Nongsang jing are still extant (Li Changnian, op. cit. (35), 5). Even in manuscript, some landowner treatises proved successful further afield. On Chen Fu's treatise, see below. The Bu nongshu became popular in Anhui and Jiangxi as well as the Yangzi delta (BNS, op. cit. (31), 1).

44 See, for example, WZNS, op. cit. (23), 6-12; Xu Guangqi, Nongzheng quanshu (Complete Treatise on Agricultural Administration), 1639, in Shi Shenghan, Nongzheng quanshu jiaozhu (Annotated Critical Edition of the Nongzheng quanshu), 3 vols., Shanghai, 1979 (hereafter NZQS), 225-53. 
innovations or best practices from around the empire, urging their adoption in less advanced regions (an early form of technology transfer). A second was to provide a spectrum of experience, drawn from history, from different regions or from contrasting environments, from which the reader could select the knowledge or techniques most appropriate to local circumstances. This method worked best if the author structured the materials he quoted, using comparisons to deduce general principles that allowed the adaptation of local techniques and offering critical analysis based on his own experience.

The basic principles and methods of quannong faced many challenges and changes during the two millennia of imperial rule. Between 1100 and 1800 the typical intensive wet-rice landscape of the Yangzi delta progressively colonized most of south China's hinterlands and backwaters, and spread from river plains into wetlands and up into the mountains. ${ }^{45}$ In peaceful periods the population grew and so did pressure on land. In response, officials promoted the adoption of new crops or more intensive farming methods, and sponsored the opening up of new types of land, and migration to sparsely populated regions. ${ }^{46}$ Floods, droughts and crop failures routinely put public granaries and transport networks to the test. After rebellions, invasions or dynastic transitions that devastated vast regions, reducing fertile farmlands to waste and decimating the population, governments would hasten to organize resettlement, providing land titles, seed, oxen, loans and technical instruction. Often, as the following examples suggest, it was some form of crisis that inspired the most innovative approaches in official nongshu. ${ }^{47}$

The northern provinces of China had been ravaged by decades of warfare when the Yuan (Mongol) emperor Kublai established a Board of Agriculture ( $\mathrm{Da}$ sinong si) for his new dynasty in 1271 and commissioned a practical handbook to improve farming practices throughout the Yuan state. ${ }^{48}$ In 1273 the board directors, Meng Qi, Miao Haoqian and Chang Shiwen, presented to the throne a treatise entitled Nongsang jiyao (Compiled Essentials of Agriculture and Sericulture), which was immediately printed and distributed all over the country. The most important new information contained in the work was a 'recent, improved method of cotton cultivation' (jin tian zai mumian $\mathrm{fa})^{49}$

Cotton cloth had been imported to China as a luxury for centuries but hemp was still the commoners' alternative to silk. Cotton-processing techniques were highly

45 M. Elvin and Tsui-jung Liu (eds.), Sediments of Time: Environment and Society in Chinese History, Cambridge, 1998; Bray, op. cit. (21).

46 Often farmers would take these steps on their own initiative, but almost invariably the state would play an active supporting role.

47 As well as the examples discussed here, see also F. Bray, 'Agricultural illustrations: blueprint or icon?', in F. Bray, V. Dorofeeva-Lichtmann and G. Métailié, Graphics and Text in the Production of Technical Knowledge in China: The Warp and the Weft, Leiden, 2007, 521-67, on the scroll painting Gengzhi tu (Ploughing and Weaving Illustrated) as a response to the loss of the northern provinces by the Song government in 1127.

48 The southern Chinese provinces were not incorporated until the Yuan defeat of the Southern Song dynasty in 1279 .

49 Nongsang jiyao, Chapter 2, quoted in WZNS, Chapter 10 (op. cit. (23), 160-8). The context suggests that this method was introduced from Central Asia. 
developed in Central Asia and China's southern neighbours like Hainan, but the crop was barely known to Chinese farmers at the time. The much-travelled Mongols were quite familiar with the advantages of cotton, which was soft, light and hardwearing, warm in winter and cool in summer. Furthermore, levels of silk and hemp production had been severely affected by the wars of invasion, leaving the state short of textiles needed to pay and clothe civil servants and the army. ${ }^{\mathbf{5 0}}$

The Nongsang jiyao describes how to select the right type of soil, construct raised beds, pregerminate the seed, irrigate the beds, pinch out the seedlings and so on, right through to deseeding the bolls (the cotton gin was unknown in China until around 1300) and spinning the yarn. Wang Zhen, in his Nongshu (Agricultural Treatise), completed in 1313, says the government disseminated these techniques in order to introduce cotton where it was not yet known, and to raise standards where it was already cultivated. In 1289 the Yuan government established cotton promotion bureaux in the newly acquired southern provinces. Wang names several regions that had since taken up cotton. He noted that in many places it did as well as any native crop, and expressed the hope that it would continue to spread in both north and south. ${ }^{51}$

The Nongsang jiyao provides one single method, a general formula, for growing cotton, offering precise details, no variants and no explanations. This instruction-leaflet approach is what one might expect for a new crop untried through most of the area in which the government planned to introduce it. In these circumstances the generalized technical knowledge contained in the written text seems to have allowed for very successful decoding around the country. In terms of broader technological context, one powerful incentive for farmers to adopt cotton was that in 1296 cotton was incorporated into the tax system at very favourable rates compared to silk or hemp. ${ }^{52} \mathrm{We}$ should not forget, however, that there was also a general shortage of cloth, and merchants and markets may have been just as important as the state in promoting cotton (see below).

It is perhaps not surprising that Wang Zhen's Nongshu, completed only forty years after the Nongsang jiyao, has nothing to add on cultivation methods. ${ }^{53}$ What Wang Zhen does contribute, and this was of enormous importance, is technical plans for the processing equipment (bows, gins, spinning wheels and so on) recently introduced from China's southern neighbours. Cotton is a short-staple fibre, and it was not easy to process using the equipment developed for China's indigenous long-fibre materials, silk and hemp. The new devices were beginning to revolutionize cotton production in Songjiang prefecture (the region around Shanghai), but Wang noted that they were still little known elsewhere and should be introduced more widely. ${ }^{54}$

Wang Zhen's Nongshu was also a response to crisis. Wang was a native of Shandong province, in the north, and had spent many years as an official in Anhui and Jiangxi, in

50 K. Chao, The Development of Cotton Textile Production in China, Cambridge, MA, 1977.

51 WZNS, op. cit. (23), 161.

52 Bray, op. cit. (6), 539.

53 WZNS, op. cit. (23), 161.

54 WZNS, op. cit. (23), 416. According to a local scholar, Tao Jiucheng, writing in 1366, a woman from Hainan named Huang transformed the Songjiang economy by introducing these devices in around 1300 (quoted in NZQS, op. cit. (44), 968). See D. Kuhn, Science and Civilisation in China, Volume V: Textile Technology, Cambridge, 1988, for details concerning the development of cotton-processing equipment. 
the south. Most farming regions in China were still suffering from the aftermath of decades of warfare between the Yuan and Southern Song states. Wang urged magistrates to acquire a thorough practical understanding of the best agricultural methods currently available, in order to instruct the peasants under their jurisdiction. His treatise provided informed and accurate documentation of effective tools and methods from around China; he was especially interested in technology transfer between north and south.

Wang Zhen's treatise follows the basic method of documenting existing high-quality practices in order to facilitate their dissemination; in other words, he is not creating new knowledge, but facilitating its circulation. Most of the sections on cultivation methods consist principally of quotations from earlier works. Perhaps Wang's most important contribution here was to incorporate the detailed instructions for the sophisticated techniques of wet-rice cultivation set out by Chen Fu in 1149, thus making them easily available throughout China. These intensive methods gradually spread to the provinces of the middle Yangzi and the far south, continuing to offer useful guidance in less-developed regions long after they were written. ${ }^{\mathbf{5 5}}$

Wang Zhen's truly innovative contribution to agronomy, however, was his development of a new method of encoding technical information, pairing text with illustrations and diagrams in a kind of blueprint. The medium of woodblock printing lent itself to such forms of organizing and transmitting knowledge, and technical illustrations $(t u)$ were developed in a range of fields during the Song dynasty (960-1279), including architecture, astronomy and cosmology. ${ }^{56}$ But Wang Zhen was the first to apply the principles of technical illustration to agronomy. ${ }^{57}$ The third section of his Nongshu, the Nongqi tupu (Illustrated register of agricultural equipment), pairs illustrations and text in a systematic inventory of field types, farming implements and equipment, from watermills to sandals, from harrows to machines for reeling silk. The text lists the structural elements of a piece of equipment, giving materials, dimensions, and how they are connected; the illustration provides an overall view of the complete structure (Figure 2).

According to Wang Zhen's friend and fellow prefect Dai Biaoyuan, as well as interviewing the local farmers about their methods Wang 'also made drawings [tuhua] of all the varieties of hoes, drills, harrows, and other miscellaneous implements, and had the common people make them [shi min wei zhi]', a method which initially caused merriment among his colleagues and bewilderment among the farmers, but which showed its value in disseminating best practices in just a few years. ${ }^{58}$ In other words, Wang was at pains not only to encode the knowledge of these implements in detail, but also to test whether the inscription could be decoded and rematerialized successfully. One essential

55 Although important advances were made subsequently in fertilizing techniques, crop-breeding and water control, much of Chen Fu's technical advice remained valid.

56 F. Bray, 'Introduction: the powers of $t u$ ', in F. Bray, V. Dorofeeva-Lichtmann and G. Métailié, Graphics and Text in the Production of Technical Knowledge in China: The Warp and the Weft, Leiden, 2007, 1-78.

57 Bray, op. cit. (47).

58 Wang Boshan nongshu xu (Preface to Wang Boshan's Agricultural treatise), in WZNS, op. cit. (23), 445. 


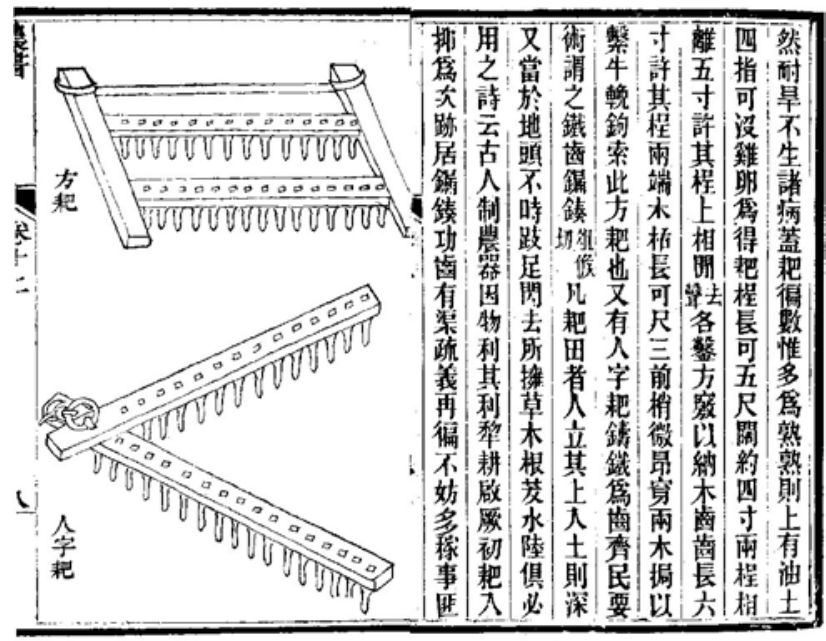

Figure 2. Wang Zhen's pictures and textual descriptions of harrows. Nongshu (Agricultural Treatise), 1783 Palace edition, Chapter12, 8a.

partner in this exercise of decoding was a carpenter (mujiang), whose familiarity with routine solutions to complex mechanical problems Wang assumed would fill in any technical gaps in his encoding. ${ }^{\mathbf{5 9}}$

Wang's hope was that officials would make use of his work to introduce more advanced technology to backward regions, and to disseminate various items of laboursaving or helpful equipment to areas where they were unknown. This motif occurs repeatedly in the opening sections of the Nongshu, for instance in the chapter on harrowing (balao) and the many different types of harrow that existed for stirring the mud in rice paddies, smoothing seed into dry-land furrows, creating a soil mulch and so on. 'I am including all of them here', says Wang, 'so that northern and southern knowledge can be exchanged, and people can use whatever is most suitable'. ${ }^{60}$ And indeed the various types of harrow are all meticulously illustrated and described in the corresponding Nongqi tupu section. ${ }^{61}$ Unfortunately, Wang's ambition for north-south technical exchange of implements like harrows, seed-drills or weeding-rakes was never realized. It is possible that it was never attempted by even the most optimistic local magistrate. Wang neglected to consider that these individual tools were embedded in technical systems: a seed-drill, however efficient in the dry soils of the north, simply did not fit with the wet soils and tillage techniques of the south. Perhaps Xu Guangqi (see below) was not entirely wrong to say that Wang Zhen was a better poet than he was a farmer. ${ }^{62}$

59 For example the 'very complicated' rotating mechanism of the pallet-chain water-pump, WZNS, op. cit. (23), 326.

60 WZNS, op. cit. (23), 27.

61 WZNS, op. cit. (23), 205-7.

62 NZQS, op. cit. (44), 123. 


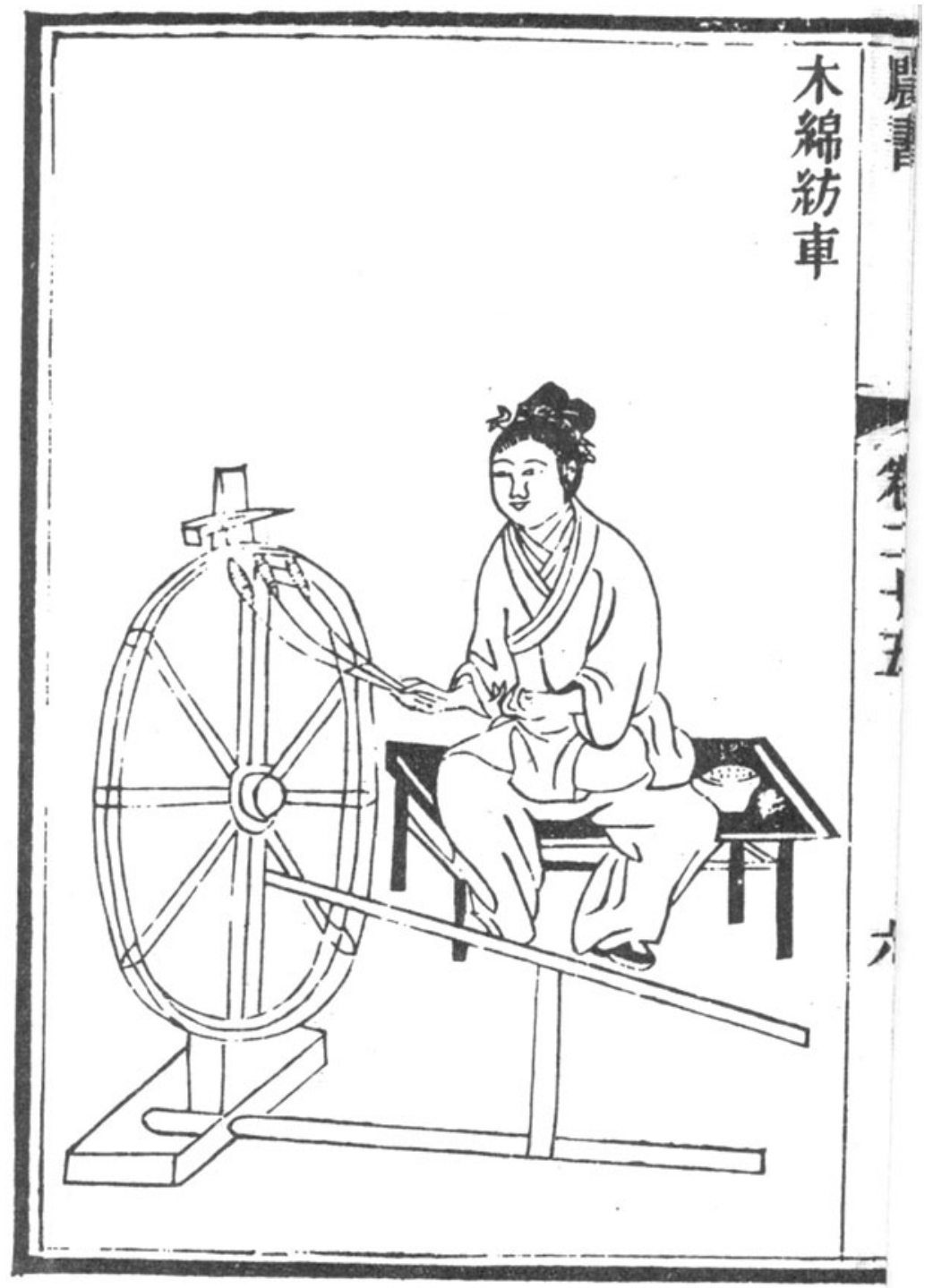

Figure 3. Spinning wheel for cotton. Wang Zhen's Nongshu (Agricultural Treatise), 1783 Palace edition, Chapter 25, 6a.

In the case of the cotton-processing implements, the gin, bow, spinning wheel and multi-bobbin reels which Wang Zhen describes for the first time in his 'Illustrated register' (Figure 3), his accounts seem to have passed muster even with the exigent Xu, who adds only a few notes explaining minor changes in structure or operation. ${ }^{63}$ Here Wang's hope for diffusion was realized: these implements were gradually adopted

63 WZNS, op. cit. (23), 415-20; NZQS, op. cit. (44), 275-9, and see Shi Shenghan's comments, in ibid., 989-90. 
throughout China. Although we have no way of pinpointing exactly what contribution the 'Illustrated register', or official instruction, may have made to this process of innovation, local officials certainly used the work as a reference for providing instruction in processing techniques, or for setting up teaching workshops. ${ }^{64}$ But merchants and migrants must also have played a role in disseminating this technical information; Wang Zhen himself mentions that merchants had played a role in the early dissemination of cotton cultivation. ${ }^{65}$

My final examples of innovative official approaches to agronomy in response to crisis come from the distinguished statesman and polymath Xu Guangqi (1562-1633). ${ }^{66}$ From the mid-fifteenth to the late sixteenth century the Ming dynasty (1368-1644) flourished. Farming prospered and farmers were steadily integrated into national and international networks of commerce; the population increased rapidly, cities grew, markets expanded and print culture exploded. But by the early 1600s pressure on resources and climatic shifts brought hardship and rebellions, weakening the state and exposing its frontiers to invasion. Like many of his contemporaries, Xu Guangqi devoted his life to seeking solutions to the desperate crisis of the late Ming. 'His exhaustive researches on natural and social phenomena were all directed towards shiyong [the practical application of knowledge in pursuit of social order] - and what preoccupied him the most were agricultural matters', noted the editor of Xu's monumental Nongzheng quanshu (Complete Treatise on Agricultural Administration), published posthumously in $1639 .{ }^{67}$ The use of the term zheng, 'administration', in Xu's title is not fortuitous. The work addresses three levels of official engagement: national policy, regional organization of infrastructure and local campaigns to improve technical skills. At each level, wrote $\mathrm{Xu}$, 'you will only succeed if you pay attention to the details ${ }^{68}$ No previous agronomist collected and deployed such a rich and varied range of empirical data as Xu.

$\mathrm{Xu}$ began his apprenticeship in farming techniques as a boy when his father, a failed scholar, set up a market garden in Shanghai. As his official career progressed Xu travelled extensively through China, and he always made time for intensive discussions with local farmers, carefully recorded. As well as the family plot in Shanghai, Xu later purchased land outside Tianjin in north China; he used both farms for comparative experiments with crops and fertilizers. ${ }^{69}$

One issue to which Xu Guangqi devoted considerable effort was the improvement of the production of cotton, by then China's most important crop after rice. As the long

64 See Kuhn, op. cit. (54), on state programmes for introducing or improving sericultural techniques during the Song, and P.-E. Will, 'Développement quantitatif et développement qualitatif en Chine à la fin de l'époque impériale', Annales histoire, sciences sociales (1994), 49, 863-902, on late Ming and early Qing official schools for teaching textile techiques.

65 WZNS, op. cit. (23), 414.

66 C. Jami, P. Engelfriet and G. Blue (eds.), Statecraft and Intellectual Renewal in Late Ming China: The Cross-Cultural Synthesis of Xu Guangqi (1562-1633), Leiden, 2001.

67 Chen Zilong's preface, Fanli, in NZQS, op. cit. (44), 4-5.

68 Quoted Li Changnian, 'Xu Guangqi di nongzheng sixiang', Zhongguo nongshi (1983), 3, 5. Many of Xu's close associates were similarly concerned with the integration of technical improvements into administrative reforms, for instance in the field of water control (see NZQS, op. cit. (44), 337-82).

69 F. Bray and G. Métailié, 'Who was the author of the Nongzheng quanshu?', in Jami, Engelfriet and Blue, op. cit. (66), 322-59. 
chapter on cotton in the Nongzheng quanshu demonstrates, in the three centuries since the Nongsang jiyao enormous technical progress had been made in cultivation methods, especially in fertilization (cotton needs lots of nutrients) and in adapting the crop to a wide range of soils; however, cultivation standards were very uneven. In his late forties $\mathrm{Xu}$ published a short monograph, Jibei shu (Comments on Cotton), to 'explain the many complications of growing cotton. Fearing that they had not reached all farming households, I had the work printed so as to circulate the information. ${ }^{70}$ The Jibei shu was incorporated into the much longer chapter on cotton in the Nongzheng quanshu ( $\mathrm{Xu}$ continued to add to his materials till his death), but $\mathrm{Xu}$ notes the pedagogical limitations of the written form:

Some of this information will still not have reached the illiterate, so now I am including four maxims $[y a n]$. If those who can read will simply teach them these sayings, even women and children will be sure to grasp [the principles] completely: ‘(1) Select unmixed seed-kernels; (2) sow the seed early; (3) roots deep, stems short; (4) plants well spaced and well banked up. ${ }^{71}$

In his writings on cotton, as on other agronomic topics, $\mathrm{Xu}$ goes beyond recording specific technical methods to seek general principles. He provides detailed discussions of each step in the cultivation process, engaging in close critical dialogue with local works written by landowners as well as official nongshu. Xu remarks that while it is tempting to criticize failings in the techniques proposed by earlier writers like Meng Qi, improvements were continuous and he realizes that his own advice may soon be outdated. ${ }^{72}$ Each passage $\mathrm{Xu}$ quotes is situated in time and space, its techniques tested against evidence from other authors and against the data that $\mathrm{Xu}$ himself has collected from around the country, thus offering a spectrum of practices corresponding to different environments. For each procedure (fertilizing, hoeing and so on) $\mathrm{Xu}$ then provides a set of general considerations and instructions that would apply under any conditions (unlike landowner nongshu, which pick out only those which apply locally). ${ }^{73}$

Xu's researches also aimed to reform the technology, the socio-economic organization, in which farming techniques were embedded. His proposals concerning cotton production are a good example. Cotton was grown almost everywhere in China, whatever the soils or climate. Northern cottons were the finest, but, because cotton fibres snap easily in dry air, spinning and weaving were still largely confined to the humid south, and the centre of the weaving industry was Xu's native district, Songjiang. Though cotton was grown in Songjiang, the methods, said $\mathrm{Xu}$, were derided as primitive by farmers elsewhere. ${ }^{74}$ Cotton merchants made fortunes from exploiting this regional division of labour, buying raw cotton cheaply in the north, shipping it south to

70 NZQS, op. cit. (44), 975.

71 NZQS, op. cit. (44), 975. As well as maxims, official agronomists often used simple poems to popularize technical knowledge. Wang Zhen ended each entry in his 'Illustrated register' with a short ditty of his own composition, or by an earlier official like the famous Song statesman Wang Anshi.

72 NZQS, op. cit. (44), 963.

73 For example the Nongsang jing, quoted in Chen Zugui (ed.), Mian (Cotton), Shanghai, 1957, 78. For more examples of Xu's innovations in agronomy, see Bray and Métailié, op. cit. (69).

74 NZQS, op. cit. (44), 964. 
the lower Yangzi workshops, and selling the cotton cloth all over China and beyond. $\mathrm{Xu}$ was convinced that farmers across China would benefit if they could both grow good-quality cotton and process it locally; officials should help local farmers match cultivation methods to local conditions and gradually improve the quality of their products. ${ }^{75}$ At the beginning of the seventeenth century the peasants of Suning in Hebei had discovered that cotton could be spun and woven during the northern summer if it was done in underground cellars where humidity could be conserved. $\mathrm{Xu}$ describes these cellars in some detail, noting that the quantity, quality and price of Suning cloth had risen rapidly in just a couple of decades, reducing the region's dependence on imports. The government, Xu said, should heed these price and supply differentials and devise policies to reduce regional inequalities; in each district it should be possible to manage gradual but steady improvement, culminating in a high level of local selfsufficiency in cloth. ${ }^{76}$

By the late Ming, farmers across China were tied into networks of local or longdistance trade, often concentrating entirely on commercial production and buying rice and cloth on the open market. Master Shen's calculations reflect the concerns of farmers around the country evaluating the relative profits $(l i)$ of silk or rice, sugar, tea or paper. Like the majority of his official colleagues, however, Xu Guangqi was acutely aware of the vulnerability of farming households to natural disaster, national shortages or market fluctuations. Against short-term calculations of profits, over-specialization and a wholehearted embrace of the market economy, he urged a rebuilding of local self-sufficiency. Without insisting that farmers abandon commercial production, $\mathrm{Xu}$ urged them to diversify: to plant sweet potatoes and manioc to feed their pigs in good years but to eat them themselves if the rice crop failed, to grow commercial crops on marginal land instead of converting their rice fields. For Xu and his fellow officials, the concept of $l i$ could not and should not be reduced to financial profit. Promoting the 'welfare of the people' (limin) was a long-term endeavour all too easily undermined by the pursuit of short-term gain. ${ }^{77}$

\section{Concluding remarks}

Unlike other sciences of state in late imperial China, such as astronomy and calendrical science, the science of agronomy, nong, was a domain of collective complementary knowledge production that spanned the political spectrum rather than being restricted to specialist imperial bureaux or to members of the educated elite. ${ }^{78}$ 'Old farmers' or 'peasants' were acknowledged by authors of agricultural treatises as primary sources for empirical observations of nature, and as experts in material skills and techniques. Serving officials were expected both to use and to contribute to the agronomic corpus,

75 NZQS, op. cit. (44), 970.

76 NZQS, op. cit. (44), 970-1.

77 Bray and Métailié, op. cit. (69).

78 On the varying forms and levels of state control over astronomical and military expertise through late imperial times see, for example, J. Waley-Cohen, The Sextants of Beijing: Global Currents in Chinese History, New York, 1999. 
collecting and processing local expertise for broader dissemination, or introducing suitable methods gleaned from the corpus. Officials were highly educated men, experts in techniques for encoding knowledge in textual or graphic forms, and they had unquestioned authority to elicit technical information from farmers and craftsmen. The authors of the Nongsang jiyao documented farmers' techniques of cotton cultivation in order to spread knowledge of a valuable new crop across the empire. Wang Zhen innovated at another level. His 'Illustrated register' invited fellow officials to attend for the first time to the construction of agrarian implements or types of irrigated field, which he encoded in such a way that his educated readers should be able, in partnership with skilled carpenters and other craftsmen, to reproduce these artefacts for adoption in their own jurisdiction. Were official agronomists no more than sophisticated scribes, recording information in conveniently transmissible forms? Are the nongshu no more than compilations of techniques, or do they also operate in another analytical register?

Although science (like technology) is a concept that has no direct equivalent in imperial culture, I have argued that over time agronomic authors, both official and private, consciously developed strategies for deploying their descriptions of techniques in formats which highlighted the general principles whereby human action effected material transformations in different geographical or environmental contexts. Landowners and official authors of nongshu made contrasting claims for the validity of the knowledge they produced. Whereas landowners strove to provide detailed, precisely situated local knowledge, the goal of official agronomists was to produce mobile forms of authoritative natural knowledge that could be applied anywhere in the empire. They were aided in this quest by the very nature of official experience: officials were regularly transferred from one province to another, and their training and duties required them to become familiar with a broad spectrum of historical documents, local records and memorials on policy, thus encouraging a comparative (if not always critical) approach.

Officials wrote their works primarily for other officials, intending that they should select the advice appropriate to local conditions to instruct local farmers. These farmers were thus at once a source of information and the practising experts who tested or contested the validity of the scientific principles and technical knowledge contained in the nongshu. Authors like Xu Guangqi incorporated objections or failures into a treatment of agronomy that was specifically self-critical and provisional.

Official agronomy tended to occlude the role of literate, landowning farmers, emphasizing collaboration between officials and peasants as the foundation of the social and cosmological order. In practice, however, landowner farmers were among the (most critical) readers of official nongshu, purchasing them from commercial publishing houses and drawing on them selectively and critically in their farming practice and in their production of new treatises. Literate landowner farmers were also important interlocutors of local officials in campaigns to 'promote farming'. Indispensable as partners in the organization of infrastructural works, they also often took on the role of 'instructor farmers' entrusted with the task of disseminating improved techniques among the local population. This brings me to technology, the web of cultural and social values and relationships within which science is validated, and the power of agronomic science as a tool of governance. 
In a scathing indictment of modern farming models and their universalist pretensions, James C. Scott offers the interesting suggestion that the urge of modern planners to generate simple, legible landscapes (such as the vast cornfields of Iowa) stems from 'a certain aesthetic, what one might call a visual codification of modern rural production and community life' ${ }^{79}$ States need this categoric conformity in order to govern, says Scott, but oversimplification diminishes the effectiveness of government and, by failing to incorporate metis (flexible, locally rooted practical knowledge) into its science, it deprives the system of resilience and renders populations vulnerable.

The 'good science' of imperial Chinese agronomy reflected an equally potent aesthetic, crystallized in an iconic landscape of tiny fields yielding rich and varied produce thanks to the skilled labours of myriad peasant farmers (Figure 1). This aesthetic, like imperial agronomic knowledge, was a joint production of small farmers, landowners and officials, dating back at least to the twelfth century. ${ }^{80}$ The Chinese state played a central role in codifying and disseminating the technical knowledge, and in financing and organizing the material infrastructure, needed to implant these ideal landscapes in new territories. But the knowledge the state deployed, like the concrete contours of the landscape, also expressed the knowledge and skills of local farmers, whether peasants or landowners, and broadly accommodated their goals. In terms of how technical practices were embedded into a technological system, landowners were concerned with $l i$ in the sense of profit, whereas officials were expected to promote the welfare, $l i$, of the local peasantry. Yet these apparently divergent goals of landlord and official science were largely compatible within the context of the imperial rice-based farming system, where landlords did not need to evict tenants and farm vast estates in order to extract the rents they needed, and experienced peasants were known to farm as well as any landlord. Although the state might intervene to control what it regarded as landlord excesses, ${ }^{81}$ there was no fundamental contradiction between the interests of landlord farming and state fiscality or approved social order. Thus technical knowledge could circulate freely, as relatively hard facts, between peasants, landowners and officials, and the compatibility of technological codes was certainly a significant factor in the resilience of this iconic landscape, even as the economy it supported developed in complexity and productivity.

I am certainly not the first person to point to the importance of state interventions in farming practice as a tool of governmentality in imperial China. But by recasting the analysis in such a way as to highlight the passages between science, technique and technology, and by relating the making of politically powerful forms of natural knowledge explicitly to the production of the material worlds in which they were embedded, I hope to have demonstrated how this approach might contribute to enriching our understanding of science and rule not only in imperial China but in premodern societies more generally.

79 J. C. Scott, Seeing like a State: How Certain Schemes to Improve the Human Condition Have Failed, New Haven, 1998, 253, emphasis added.

80 Bray, op. cit. (47).

81 For example, attempts to reclaim excessive amounts of farmland from lakes, threatening systems of irrigation and flood control. Shiba, op. cit. (26). 